\title{
Expression of endogenous granzyme B in a subset of human primary breast carcinomas
}

\author{
SX Hu' ${ }^{2}$ S Wang', JP Wang', GB Mills', Y Zhou' and H-J Xu*,I \\ 'Department of Molecular Therapeutics, The University of Texas MD Anderson Cancer Center, Houston, TX 77030, USA; '²Department of Blood and \\ Marrow Transplantation, The University of Texas MD Anderson Cancer Center, Houston, TX 77030, USA
}

Granzyme B (GrB) is the prototypic member of a serine protease family primarily used by cytotoxic lymphocytes to kill target cells. We report here that, by immunohistochemical staining of paraffin-embedded tumour sections, GrB protein was unexpectedly detected in malignant cells of a subset of breast cancers and their adjacent reactive endothelial and mesenchymal cells in which endogenous retinoblastoma protein (pRB) is overexpressed. The identity of the endogenous GrB was further confirmed experimentally in RB-deficient breast carcinoma cell culture upon overexpression of ectopic pRB. Our finding extends the recent paradigm-shifting trend for a more diverse biological role of granzyme B, and might provide a rational basis for exploring its potential prognostic value in a variety of human cancers.

British Journal of Cancer (2003) 89, I35-139. doi:I0.1038/sj.bjc.660 I05 I www.bjcancer.com

(c) 2003 Cancer Research UK

Keywords: endogenous granzyme B; breast cancer; retinoblastoma tumour suppressor gene; nonimmune cells

Granzyme B $(\mathrm{GrB})$ is a major component of cytoplasmic granules of cytotoxic T lymphocytes (CTL) and natural killer (NK) cells (Schmid and Weissmann, 1987; Trapani et al, 1988). In cellular immune reactions, $\mathrm{GrB}$ is produced by activated cytotoxic lymphocytes and initially stored in cytoplasmic granules. These granules are exocytosed, releasing $\mathrm{GrB}$ and other cytolytic proteins, including a pore-forming protein (perforin). GrB can enter target cells by autonomously crossing the cell membrane, or via a receptor-mediated pathway, and the coexistence of perforin facilitates intracellular trafficking of GrB in the target cells (Shi et al, 1997; Motyka et al, 2000). The critical role of cytotoxic lymphocyte $\mathrm{GrB}$ in target cell apoptosis has been well established (Heusel et al, 1994; Pinkoski et al, 2001). More recently, albeit controversially (Graubert et al, 1997), GrB expression has also been detected in other normal and malignant haematopoietic (nonlymphoid) cells. These include, for example, pluripotent stem cells capable of giving rise to all haematopoietic lineages (Hampson et al, 1992), CD34 ${ }^{+}$haematopoietic progenitor cells mobilised by chemotherapy and granulocyte colony-stimulating factor (Berthou et al, 1995), acute myeloblastic leukaemic cells under genotoxic stress (Bruno et al, 2000) and Kupffer cells (specialised macrophages in liver) (Tordjmann et al, 1998). In addition, activated keratinocytes are able to protect against invading pathogens through expression of endogenous $\mathrm{GrB}$ and perforin (Berthou et al, 1997), whereas perforin-independent expression of $\mathrm{GrB}$ and its specific inhibitor, proteinase inhibitor

\footnotetext{
* Correspondence: Dr H-J Xu, Department of Molecular Therapeutics, The University of Texas MD Anderson Cancer Center, I5 I5 Holcombe Blvd, Box 317, Houston, TX 77030-4009, USA;

E-mail: hongjixu@mail.mdanderson.org

Received 29 October 2002; revised 27 March 2003; accepted 10 April 2003
}

9 (PI-9), in human testis and placenta may play a role in reproduction (Hirst et al, 2001). Also of relevance is a recent report showing that $\mathrm{GrB}$ was distributed in primary breast and lung cancer cells rather than in tumour-infiltrating lymphocytes (TILs) (Kontani et al, 2001). In the latter study, the authors assume cancer cells may acquire GrB released from TIL. These observations inspire speculation that under certain circumstance, endogenous $\mathrm{GrB}$ may be expressed directly in nonhaematopoietic tumour cells, which is strongly supported by the results of our present work. We also report for the first time that there is apparent correlation between endogenous $\mathrm{GrB}$ and $\mathrm{pRB}$ expression in breast tumour specimens.

\section{MATERIALS AND METHODS}

\section{Tumour specimens}

Paraffin-embedded tissue sections of primary breast carcinoma specimens were obtained from the archives of the Department of Pathology at The University of Texas MD Anderson Cancer Center. They were randomly selected among cases there were plenty of tissues available from the tumour bank, and patients who had been operated before other therapy.

\section{Immunochemistry and Western blotting}

Immunohistochemical staining of $\mathrm{pRB}$ and $\mathrm{GrB}$ proteins in breast tumours was carried out on formalin-fixed, paraffin-embedded tissue sections with an antigen retrieval protocol as previously described (Xu, 1995; Yakirevich et al, 1999). The anti-RB antibody RB-WL-1 (Xu, 1995) and anti-GrB monoclonal antibody B18.1 or GrB7 (Alexis) were used. After antibody binding, the slides were processed for colour development using the avidin-biotinylated peroxidase method, and were counterstained with Mayer's 
haemotoxylin. All slides were coded, and the pRB and GrB staining results were scored separately by two investigators. Immunostaining and Western blotting detection of $\mathrm{pRB}$ and $\mathrm{GrB}$ proteins in cultured cells were done as described (Zhou et al, 1994; Berthou et al, 1997; Pinkoski et al, 2000). For double immunofluorescence analysis of $\mathrm{pRB}$ and endogenous $\mathrm{GrB}$, anti-pRB monoclonal antibodies G3-245 (FITC-labelled mouse IgG1; PharMingen, SanDiego, CA, USA) and B18.1 (Texas Red-labelled mouse IgG2a) were used. Digital images were acquired by confocal laser scanning microscopy (CLSM) (Zeiss LSM 210, Thornwood, NY, USA).

\section{Ribonuclease protection assay (RPA) and Northern blotting}

A multiprobe template set for human apoptosis-related genes (hAPO-1; PharMingen) was used for RPA, which was done according to the manuals. Northern blot analysis was conducted on total RNA (PBL) or mRNA (MDA-MB-468) samples $\left(2 \mu \mathrm{glane}^{-1}\right)$, using ${ }^{32} \mathrm{P}$-labelled full-length $\mathrm{GrB}$ cDNA probe and $\beta$-actin cDNA probe (for rehybridisation). After exposure to a storage phosphor screen, quantitative comparison of endogenous $\mathrm{GrB}$ transcript levels between the samples was carried out by using a Storm 860 PhosphorImager system and ImageQuant software (Molecular Dynamics, Piscataway, NJ, USA), and fold increases in transcription were calculated based on the PhosphorImager counts of $G r B$ bands adjusted for counts of $\beta$-actin bands from the same samples.

\section{Deglycosylation of GrB proteins}

The conditions for hydrolysis of $\mathrm{N}$-glycosylated proteins in whole cell lysates by Endo $\mathrm{H}\left(40 \mathrm{U} \mathrm{mg}^{-1}\right.$, Boehringer, Mannheim, Germany) were optimised based on the general guidelines previously established for deglycosylation of purified glycoproteins (Trimble and Maley, 1984). Briefly, cell extracts were prepared in $50 \mathrm{~mm}$ Tris $\cdot \mathrm{Cl}(\mathrm{pH} \mathrm{8.0)}$ containing $120 \mathrm{~mm} \mathrm{NaCl}$ and $0.5 \% \mathrm{NP}-40$, and then changed into $100 \mathrm{~mm}$ phosphate reaction buffer (pH 5.8) by using Bio-Spin 6 columns (Bio-Rad, Hercules, CA, USA). In the case of using denatured substrates, the cell extracts were preheated for $2 \mathrm{~min}$ at $100^{\circ} \mathrm{C}$ with 1.2 -fold weight excess of sodium dodecyl sulphate (SDS) in relation to the protein contents. The deglycosylation assays were carried out in triplicate in microfuge tubes. Each tube contained $5 \mu \mathrm{g}$ of total cellular proteins in $25 \mu \mathrm{l}$ reaction buffer, a cocktail of proteinase inhibitors, $100 \mathrm{~mm}$ of $\beta$-mercaptoethanol ( $\beta$-ME), and without Endo $\mathrm{H}$ (Tube 1 , Control), or with Endo $\mathrm{H}$ (Tubes 2 and 3 ). Cell extracts in Tube 3 were predenatured. All reaction mixtures were incubated for $18 \mathrm{~h}$ at $37^{\circ} \mathrm{C}$, and then analysed by Western blotting as described above. For in vivo deglycosylation, cells were cultured in the presence of tunicamycin ( $5 \mu \mathrm{g} \mathrm{ml}^{-1}$, Sigma, St Louis, MO, USA) overnight.

\section{RESULTS}

\section{Detection of endogenous GrB in primary breast carcinomas overexpressing $\mathrm{pRB}$}

In phytohaemagglutinin (PHA)-stimulated peripheral blood lymphocytes (PBL), coincident with the strong induction of $\mathrm{GrB}$ expression (Schmid and Weissmann, 1987; Trapani et al, 1988), pRB protein increased eight-fold, and $R B$ RNA levels increased 24 -fold (Furukawa et al, 1990). The same appears to hold for the primary keratinocytes in culture. While human keratinocytes grown in vitro reportedly synthesised endogenous GrB protein (Berthou et al, 1997), we observed that these activated keratinocytes also had elevated pRB expression (data not shown). Therefore, to address the issue of whether breast cancer cells can produce their own $\mathrm{GrB}$, a total of 25 randomly selected breast carcinomas were examined for endogenous $\mathrm{pRB}$ and $\mathrm{GrB}$ expression.

As illustrated in Figure 1A, by immunohistochemical staining of routinely processed pathological specimens, we found that five of the 25 breast tumours were $\mathrm{pRB}^{-}$, that is, loss of $\mathrm{pRB}$ staining occurred in every malignant cell of the tumours. In these $\mathrm{pRB}^{-}$ tumours, some (but not all) of the reactive stromal cells were stained positively for $\mathrm{pRB}$, which was consistent with the view ; that expression of $\mathrm{pRB}$ in normal tissues was regulated by their proliferation and differentiation states (Xu et al, 1991a,b; Shan et al, 1994; Cordon-Cardo and Richon, 1994). Malignant cells of the five $\mathrm{pRB}^{-}$breast tumours were all negative for $\mathrm{GrB}$, although there were clearly $\mathrm{GrB}^{+}$TILs in immediately adjacent tumour stroma; the latter served as an excellent internal control for validating the GrB staining (Figure 1B). Second, 17 of the 25 cases fulfilled the established criteria for $\mathrm{pRB}^{+}$tumours (Cance et al, 1990; Xu et al, 1991a, b; Xu, 1995), that is, the observed pRB immunoreactivity patterns in these tumours were highly heterogenous, and the staining intensity was not uniform among the tumour cells, with more or less of the tumour cell nuclei stained positively (Figure 1C). In the majority (16 out of 17 ) of the $\mathrm{pRB}^{+}$cases, all tumour cells stained negatively for GrB, while TILs in the same tumour sections were $\mathrm{GrB}^{+}$(Figure 1D). Third, the remaining three tumours expressed extremely high levels of $\mathrm{pRB}$ as determined by their uniformly high intensity of $\mathrm{pRB}$ staining $\left(\mathrm{pRB}^{++}\right.$, Figure $\left.1 \mathrm{E}\right)$ (Cote et al, 1998). In these three $\mathrm{pRB}^{++}$and one $\mathrm{pRB}^{+}$tumours, GrB staining was readily detected in many tumour cells as well as in nonlymphoid reactive stromal cells, including endothelial and mesenchymal cells (Figure 1F, G). The intensity of the endogenous GrB staining was variable, with some areas exhibiting typical granular or dot-like cytoplasmic and nuclear staining (Figure 1G). In this small cohort study, the correlation between endogenous $\mathrm{GrB}$ and $\mathrm{pRB}$ protein expression in malignant cells appeared to be very significant $(P<0.001)$, although an inadequate sample size for statistical calculation has precluded a more definitive conclusion (Table 1). On the other hand, the number of TILs with $\mathrm{GrB}^{+}$ staining was variable within the same cohort, and in general was unrelated to the $\mathrm{pRB}$ status of the tumour specimens (Figure $1 \mathrm{~B}, \mathrm{D}$ and $\mathrm{H}$ ). Two proven anti-granzyme B antibodies, B18.1 (Berthou et al, 1997) and GrB7 (Kummer et al, 1993), were used for the studies with essentially similar results.

\section{Evidence from culture: confirmation of endogenous $\mathrm{GrB}$ expression in breast cancer cells}

Until recently, expression of $\mathrm{GrB}$ has been implicated solely in lymphoid cells. The discovery of GrB in nonlymphoid cells, such as mobilised haematopoietic $\mathrm{CD} 34^{+}$progenitor cells, epidermal keratinocytes, testis and placenta (Berthou et al, 1995, 1997; Hirst et al, 2001), challenged the existing, perhaps oversimplified model for GrB function. In these latter studies, however, expression of the $G r B$ mRNA was demonstrated only by in situ hybridisation using antisense $G r B$ RNA probes. The method was not able to determine the extent of the nucleotide sequence identity between more or less closely related RNA species, nor the size of the transcripts. An independent study reported by others failed to detect $\operatorname{GrB}$ mRNA expression in mobilised haematopoietic $\mathrm{CD} 34^{+}$progenitor cells when an S1 nuclease protection assay was employed (Graubert et al, 1997).

To further validate our finding of endogenous $\mathrm{GrB}$ in primary breast cancer, we conducted in vitro experiments to confirm the identity of the $\mathrm{GrB}$ protein and messenger RNA, and the correlation between induction of endogenous $\mathrm{GrB}$ and overexpression of $\mathrm{pRB}$. This was accomplished by using a panel of $R B$ reconstituted MDA-MB-468 breast carcinoma cell lines (Xu et al, 1997) in which expression of $\mathrm{pRB}$ is tightly controlled by tetracycline ( $\mathrm{Tc})$. The ectopic $\mathrm{RB}$ protein expressed in these cell clones reach the highest level about $24 \mathrm{~h}$ after removal of $\mathrm{Tc}$ from the cell culture medium, and will then become totally 
pRB

GrB
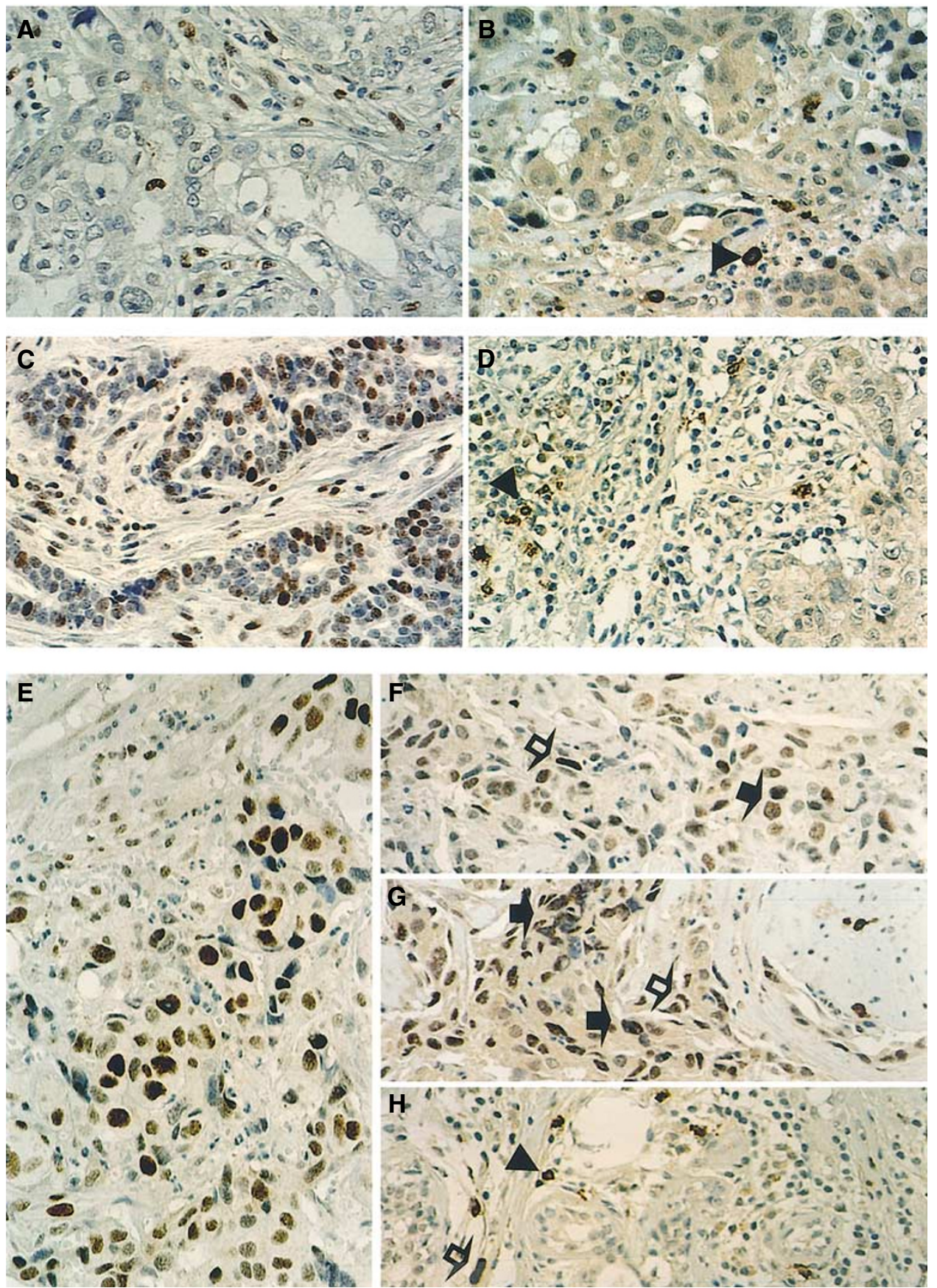

Figure I Detection of endogenous $\mathrm{GrB}$ in primary breast carcinomas overexpressing pRB ( $\mathrm{pRB}{ }^{++}$) by immunohistochemical staining of paraffinembedded tissue sections. (A, C, E) pRB staining, showing typical pRB ${ }^{-}(\mathbf{A}), \mathrm{pRB}^{+}(\mathbf{C})$, and $\mathrm{pRB}^{++}(\mathbf{E})$ tumours. Note that the tumour cells in panel $\mathbf{E}$ $\left(\mathrm{pRB}^{++}\right)$display uniformly strong $\mathrm{pRB}$ staining, while the tumour cells in panel $(\mathbf{C})\left(\mathrm{pRB}{ }^{+}\right)$show nuclear staining heterogeneity of the RB protein, ranging from quite positive to seemingly negative $(\mathrm{Xu}$, 1995). (B, D and $\mathbf{F}-\mathbf{H})$ The same tumours corresponding to the left panels were stained for $\mathrm{GrB}$. Panels $\mathbf{B}$ and $\mathbf{D}$, in either $\mathrm{pRB}^{-}(\mathbf{B})$ or $\mathrm{pRB}{ }^{+}(\mathbf{D})$ tumours, malignant cells are $\mathrm{GrB}$ negative, but some infiltrating lymphocytes are GrB ${ }^{+}$. Panels $(\mathbf{F}-\mathbf{H})$, representative areas of the same pRB ${ }^{++}$tumour shown in Panels $\mathbf{E}$. GrB ${ }^{+}$tumour cells $(\mathbf{F}, \mathbf{G})$, or lymphocytes $(\mathbf{H})$ were evident. Note the finely granular distribution of endogenous GrB protein in tumour cells of panel $(\mathbf{G})$. Arrowheads, GrB ${ }^{+}$lymphocytes; solid arrows, $\mathrm{GrB}^{+}$tumour cells; open arrows, GrB; mesenchymal and endothelial cells. Scale bar, $50 \mu \mathrm{m}$.

dephosphorylated within 24-40h (Xu et al, 1997). The levels of $\mathrm{pRB}$ expression in these cultured cells in Tc-free medium were comparable to the elevated pRB expression in subsets of primary tumours (Xu, 1995; Xu et al, 1997; Cote et al, 1998 and compare Figures $1 \mathrm{E}$ with $3 \mathrm{~A}$, panel $\mathrm{b}$ below). Both ribonuclease protection assay (RPA) and Northern blot analysis showed that the endogenous $G r B$ mRNA levels were increased up to 16-fold in
$R B$-reconstituted MDA-MB-468 tumour cells after removal of Tc for 4 days (Figure 2). The Northern blotting results also suggested that the endogenous $\operatorname{GrB}$ mRNA detected in breast tumour cells was slightly larger than the $G r B$ mRNA from IL-2-stimulated peripheral blood lymphocytes (PBL) (Figure 2). The difference in transcript sizes is owing to differential usage of upstream transcription start sites at the $\mathrm{GrB}$ locus (Xu HJ et al, unpublished data). 
Table I Correlation between endogenous GrB and pRB protein expression in breast cancers

\begin{tabular}{lcc}
\hline & \multicolumn{2}{c}{ Endogenous GrB expression } \\
\cline { 2 - 3 } pRB status & $\mathbf{G r B}^{-}$ & $\mathbf{G r B}^{+}$ \\
\hline $\mathrm{pRB}^{-}(n=5)$ & 5 & 0 \\
$\mathrm{pRB}^{+}(n=17)$ & 16 & 1 \\
$\mathrm{pRB}^{++}(n=3)$ & 0 & 3 \\
\hline
\end{tabular}

Values are number of specimens. The correlation between $\mathrm{Gr} B$ and $\mathrm{pRB}$ expression was significant $\left(P<0.00 \mathrm{I}\right.$, calculated using the $\chi^{2}$ method). Computation was performed with the STATA statistical software (Computing Resource Center, Santa Monica, CA, USA)
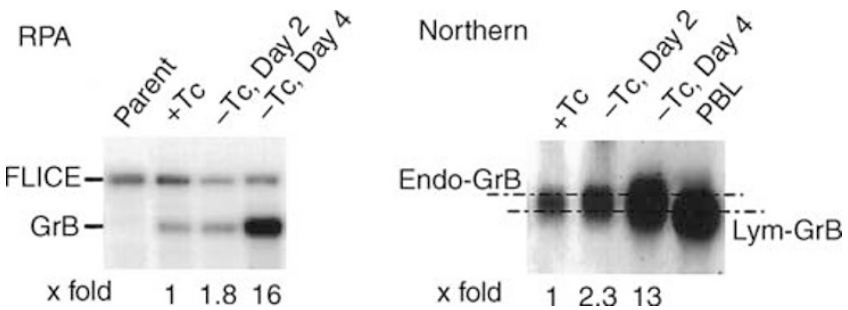

Figure 2 Transcriptional upregulation of endogenous $G r B$ in $R B-$ reconstituted MDA-MB-468 breast carcinoma cells. RPA and Northern blotting analyses were performed on RNAs extracted from parental MDAMB-468 (pRB $\left.{ }^{-}\right)$and a representative Tc-regulated RB-reconstituted clone at each indicated day. ( $+\mathrm{Tc}$ ) medium containing $0.5 \mu \mathrm{g} \mathrm{m} \mathrm{m}^{-1}$ of $\mathrm{Tc} ;(-\mathrm{Tc})$ Tc-free medium. An RNA sample from PBL of healthy donors cultured in the presence of $50 \mathrm{U} \mathrm{ml}^{-1}$ of $\mathrm{IL}-2$ was included in the Northern blot as GrB-positive control. Note that Endo-GrB mRNAs are slightly larger than the Lym-GrB mRNA on the Northern blot. The numbers under the blots indicate the fold increases in Endo-GrB transcription. Similar results were obtained with three independent clones of RB-reconstituted MDA-MB-468 breast carcinoma cells (data not shown)

Immunocytochemistry and double immunofluorescence staining of $\mathrm{pRB}$ and $\mathrm{GrB}$ showed that endogenous GrB protein (Endo$\mathrm{GrB}$ ) was accumulated in the $\mathrm{pRB}^{+}$(in Tc-free medium), but not in the $\mathrm{pRB}^{-}$(in medium containing $0.5 \mu \mathrm{g} \mathrm{ml}^{-1}$ of Tc) MDA-MB468 tumour cells (Figure 3A). Endo-GrB was located both in cytoplasm and nuclei of the $R B$-reconstituted tumour cells (Figure 3A); a comparable pattern was observed for IL-2-activated PBL GrB (Lym-GrB). Western blotting revealed Endo-GrB protein triplets from the $R B$-reconstituted MDA-MB-468 cells with apparent molecular masses $\left(M_{\mathrm{r}}\right)$ of 26,33 and $39 \mathrm{kDa}$ (Figure $3 \mathrm{~B}$ ). By SDS-PAGE, the $33-\mathrm{kDa}$ Endo-GrB protein band is identical to the mature glycosylated Lym-GrB protein from human PBL. The $39-\mathrm{kDa}$ protein was markedly increased in the tumour cells after overexpression of pRB. An in vitro hydrolysis assay using endoglycosidase $\mathrm{H}$ (Endo $\mathrm{H}$ ) revealed that, after deglycosylation, the $39-\mathrm{kDa}$ Endo-GrB and the 33-kDa Lym-GrB migrated to an identical position corresponding to a reduced $M_{\mathrm{r}}$ of $26 \mathrm{kDa}$ (Figure 3C). When the $R B$-reconstituted MDA-MB-468 cells were cultured in the presence of tunicamycin, an inhibitor of glycosylation, a partially deglycosylated $39-\mathrm{kDa}$ Endo-GrB protein appeared at $\sim 36 \mathrm{kDa}$ (Figure 3C, lane 8). Human GrB cDNA contains a single open reading frame encoding a preproenzyme of 247 amino acids. The predicted mature Lym-GrB is an active enzyme of 227 amino acids (after N-terminal cleavage by signal peptidase and dipeptidyl peptidase I [DPPI]) with an unglycosylated $M_{\mathrm{r}}$ of $26 \mathrm{kDa}$. Marked differences in apparent $M_{\mathrm{r}}$ of the mature Lym-GrB, however, have been reported in the literature, between 26 and $67 \mathrm{kDa}$, which are usually interpreted as being due to heterogeneous N-linked glycosylation (Trapani et al, 1994). Both glycosylated and nonglycosylated mature Lym-GrB are proteolytically active.
A

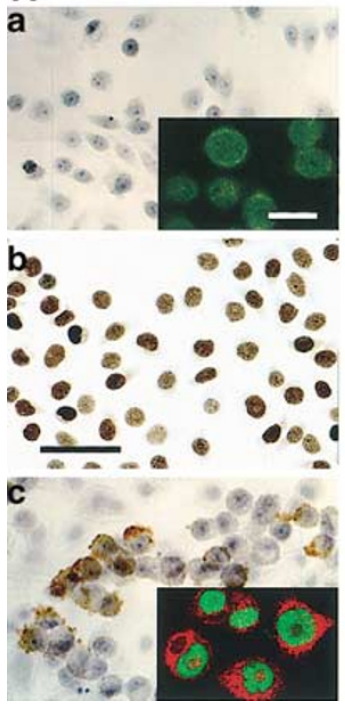

B

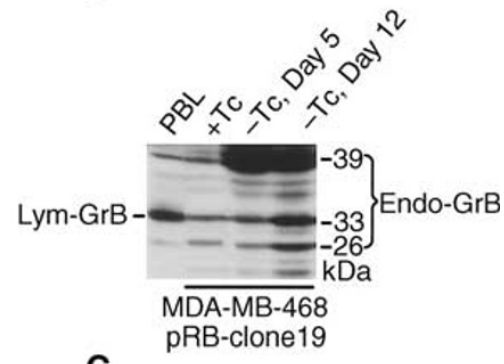

C

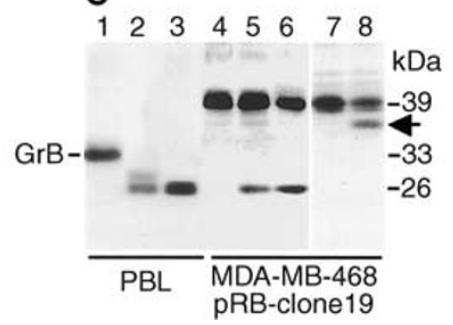

Figure 3 Characterization of endogenous $\mathrm{GrB}$ protein in RB-reconstituted MDA-MB-468 tumour cells. (A) Immunochemical staining of EndoGrB (panels $a$ and c) and pRB (panel b) of MDA-MB-468 pRB-clone 19-4. Endo-GrB was not detectable in tumour cells cultured in Tc-containing medium (Panel a), but was induced in Tc-free medium (Panel c). Tumour cells in Tc-free medium for 2 days exhibited uniformly pRB ${ }^{+}$staining (Panel b). The CLSM images shown in the inserts of Panels a and c illustrate the double immunofluorescence staining of pRB (FITC, green) and Endo-GrB (Texas Red). Scale bars, $25 \mu \mathrm{m}$ ( $12.5 \mu \mathrm{m}$ in insets). (B) Western blotting. Endo-GrB protein triplets with molecular weights of $26,33,39 \mathrm{kDa}$ were accumulated in RB-reconstituted cells grown in Tc-free medium. (C) The deglycosylated Endo-GrB and Lym-GrB proteins are identical in apparent molecular masses. Cell lysates were prepared from IL-2-activated PBL or MDA-MB-468 pRB-clone 19 cells (in Tc-free medium, Day 5). Each lane contains $5 \mu \mathrm{g}$ of total cellular proteins treated with (lanes I and 4) reaction buffer only, and (lanes 2, 3, 5 and 6) with Endo $\mathrm{H}$. Cell extracts in lanes 3 and 6 were predenatured. Following deglycosylation, both the $33-\mathrm{kDa}$ mature Lym-GrB protein (lane I) and the 39-kDa Endo-GrB protein (lanes 4) migrated to the identical position with an apparent $M_{r}$ of $26 \mathrm{kDa}$ (lanes 2, 3, 5 and 6). Also note that when small amounts of total cellular proteins $(5 \mu \mathrm{g})$ were loaded in each lane, only the major species, that is, the $33-\mathrm{kDa}$ glycosylated Lym-GrB in lane I and the 39-kDa glycosylated Endo-GrB in lane 4 were visible prior to Endo $\mathrm{H}$ treatment. (Lanes 7 and 8) The RBreconstituted MDA-MB-468 cells were cultured in the absence (lane 7 ) or presence (lane 8) of tunicamycin. Arrow indicates a partially deglycosylated Endo-GrB of $\sim 36 \mathrm{kDa}$.

\section{DISCUSSION}

In summary, we observed Endo-GrB expression in primary breast cancer cells, which appeared to be coincident with overexpression of pRB. Expression of endogenous GrB can also be manipulated experimentally by making $R B$-deficient breast tumour cells overexpressing ectopic pRB in culture. The identity of the endo-GrB was confirmed by immunochemistry, Northern blotting, Western blotting and deglycosylation. The mechanism of endo-GrB expression in breast cancer cells have yet to be established. We noticed that in paraffin-embedded breast tumour sections, germinal centres of reactive lymph nodes showed intense pRB staining, but were GrB negative (data not shown). Therefore, it seems unlikely that pRB directly regulates $G r B$ promoter in breast cancers; it is more likely that the overexpression of $\mathrm{pRB}$ mediates senescent arrest and/or terminal differentiation (Hinds and Weinberg, 1994; Xu et al, 1997), resulting in endo-GrB expression that occurs prior to the onset of the postsenescent apoptosis of the tumour cells. In this regard, Kontani et al have reported that the percentage of breast and lung cancer cells with positive GrB immunoreactivity (as mentioned above, the authors had assumed 
cancer cells acquired GrB released from TIL) was inversely correlated with regional lymph node metastasis (Kontani et al, 2001). While overexpression of pRB in primary tumours is not invariably associated with better prognosis (Cote et al, 1998), the finding of an intrinsic GrB directly expressed by human nonlymphoid tumour cells adds a new dimension to the clinical research on potential prognostic value of $\mathrm{pRB}$ expression in primary cancers. Furthermore, the diverse biological presence of GrB might be complementary to the existing paradigm for cytotoxic lymphocyte-mediated target cell death, allowing synergistic interactions between the local mechanism of defense and the immune system. We can thus look forward to intense research on both the theoretical and practical implications of endogenous $\mathrm{GrB}$

\section{REFERENCES}

Berthou C, Marolleau JP, Lafaurie C, Soulie A, Dal Cortivo L, Bourge JF, Benbunan M, Sasportes M (1995) Granzyme B and perforin lytic proteins are expressed in $\mathrm{CD}_{3} 4^{+}$peripheral blood progenitor cells mobilized by chemotherapy and granulocyte colony-stimulating factor. Blood 86: $3500-3506$

Berthou C, Michel L, Soulie A, Jean-Louis F, Flageul B, Dubertret L, Sigaux F, Zhang Y, Sasportes M (1997) Acquisition of granzyme B and Fas ligand proteins by human keratinocytes contributes to epidermal cell defense. J Immunol 159: 5293-5300

Bruno AP, Lautier D, d'Orgeix AT, Laurent G, Quillet-Mary A (2000) Acute myeloblastic leukemic cells acquire cellular cytotoxicity under genotoxic stress: implication of granzyme B and perforin. Blood 96: 1914-1920

Cance WG, Brennan MF, Dudas ME, Huang CM, Cordon-Cardo C (1990) Altered expression of the retinoblastoma gene product in human sarcomas. N Engl J Med 323: $1457-1462$

Cordon-Cardo C, Richon VM (1994) Expression of the retinoblastoma protein is regulated in normal human tissues. Am J Pathol 144: 500-510

Cote RJ, Dunn MD, Chatterjee SJ, Stein JP, Shi SR, Tran QC, Hu SX, Xu HJ, Groshen S, Taylor CR, Skinner DG, Benedict WF (1998) Elevated and absent $\mathrm{pRb}$ expression is associated with bladder cancer progression and has cooperative effects with p53. Cancer Res 58: 1090-1094

Furukawa Y, DeCaprio JA, Freedman A, Kanakura Y, Nakamura M, Ernst TJ, Livingston DM, Griffin JD (1990) Expression and state of phosphorylation of the retinoblastoma susceptibility gene product in cycling and noncycling human hematopoietic cells. Proc Natl Acad Sci USA 87: $2770-2774$

Graubert TA, DiPersio JF, Russell JH, Ley TJ (1997) Perforin/granzymedependent and independent mechanisms are both important for the development of graft-versus-host disease after murine bone marrow transplantation. J Clin Invest 100: 904-911

Hampson IN, Cross MA, Heyworth CM, Fairbairn L, Spooncer E, Cowling GJ, Dexter TM (1992) Expression and downregulation of cytotoxic cell protease 1 or Granzyme 'B' transcripts during myeloid differentiation of interleukin-3-dependent murine stem cell lines. Blood 80: 3097-3105

Heusel JW, Wesselschmidt RL, Shresta S, Russell JH, Ley TJ (1994) Cytotoxic lymphocytes require granzyme $\mathrm{B}$ for the rapid induction of DNA fragmentation and apoptosis in allogeneic target cells. Cell 76: $977-987$

Hinds PW, Weinberg RA (1994) Tumor suppressor genes. Curr Opin Genet Dev 4: $135-141$

Hirst CE, Buzza MS, Sutton VR, Trapani JA, Loveland KL, Bird PI 2001)) Perforin-independent expression of granzyme $\mathrm{B}$ and proteinase inhibitor 9 in human testis and placenta suggests a role for granzyme B-mediated proteolysis in reproduction. Mol Hum Reprod 7: 1133-1142

Kontani K, Sawai S, Hanaoka J, Tezuka N, Inoue S, Fujino S (2001) Involvement of granzyme B and perforin in suppressing nodal metastasis of cancer cells in breast and lung cancers. Eur J Surg Oncol 27: 180-186

Kummer JA, Kamp AM, van Katwijk M, Brakenhoff JP, Radosevic K, van Leeuwen AM, Borst J, Verweij CL, Hack CE (1993) Production and characterization of monoclonal antibodies raised against recombinant human granzymes $\mathrm{A}$ and $\mathrm{B}$ and showing cross reactions with the natural proteins. J Immunol Methods 163: 77-83

Lobe CG, Finlay BB, Paranchych W, Paetkau VH, Bleackley RC (1986) Novel serine proteases encoded by two cytotoxic T lymphocyte-specific genes. Science 232: $858-861$ expression in nonlymphoid cells, which may lead us in an unexpected direction.

\section{ACKNOWLEDGEMENTS}

We thank Dr Aysegul Sahin and MD Anderson Cancer Center breast tumour bank for providing the paraffin-embedded breast cancer tissue sections as well as for critical reviewing of some of the immunohistochemical staining slides. This work was supported in part by NIH Grant CA67274, The University of Texas MD Anderson Cancer Center Support Grant CA16672 and the Texas Higher Education Coordinating Board Grant ATP 003657-0159.
Motyka B, Korbutt G, Pinkoski MJ, Heibein JA, Caputo A, Hobman M, Barry M, Shostak I, Sawchuk T, Holmes CFB, Gauldie J, Bleackley RC (2000) Mannose 6-phosphate/insulin-like growth factor II receptor is a death receptor for granzyme $\mathrm{B}$ during cytotoxic $\mathrm{T}$ cell-induced apoptosis. Cell 103: $491-500$

Pinkoski MJ, Heibain JA, Barry M, Bleackley RC (2000) Nuclear translocation of granzyme B in target cell apoptosis. Cell Death Differ 7: $17-24$

Pinkoski MJ, Waterhouse NJ, Heibein JA, Wolf BB, Kuwana T, Goldstein JC, Newmeyer DD, Bleackley RC, Green DR (2001) Granzyme B-mediated apoptosis proceeds predominantly through a Bcl-2-inhibitable mitochondrial pathway. J Biol Chem 276: $12060-12067$

Schmid J, Weissmann C (1987) Induction of mRNA for a serine protease and a beta-thromboglobulin-like protein in mitogen-stimulated human leukocytes. J Immunol 139: 250-256

Shan B, Chang CY, Jones D, Lee WH (1994) The transcription factor E2F-1 mediates the autoregulation of RB gene expression. Mol Cell Biol 14: 299-309

Shi L, Mai S, Israels S, Browne K, Trapani JA, Greenberg AH (1997) Granzyme B (GraB) autonomously crosses the cell membrane and perforin initiates apoptosis and GraB nuclear localization. J Exp Med 185: $855-866$

Tordjmann T, Soulie A, Guettier C, Schmidt M, Berthou C, Beaugrand M, Sasportes M (1998) Perforin and granzyme B lytic protein expression during chronic viral and autoimmune hepatitis. Liver 18: $391-397$

Trapani JA, Klein JL, White PC, Dupont B (1988) Molecular cloning of an inducible serine esterase gene from human cytotoxic lymphocytes. Proc Natl Acad Sci USA 85: 6924-6928

Trapani JA, Smyth MJ, Apostolidis VA, Dawson M, Browne KA (1994) Granule serine proteases are normal nuclear constituents of natural killer cells. J Biol Chem 269: 18359-18365

Trimble RB, Maley F (1984) Optimizing hydrolysis of N-linked highmannose oligosaccharides by endo- $\beta$-N-accetylglucosaminidase $\mathrm{H}$. Analytical Biochem 141: 515-522

$\mathrm{Xu}$ HJ (1995) Altered retinoblastoma (RB) protein expression in human malignancies. Adv Anat Pathol 2: 213-226

Xu HJ, Hu SX, Benedict WF (1991a) Lack of nuclear RB protein staining in G0/middle G1 cells: correlation to changes in total RB protein level. Oncogene 6: 1139-1144

$\mathrm{Xu} \mathrm{HJ}, \mathrm{Hu}$ SX, Cagle PT, Moore GE, Benedict WF (1991b) Absence of retinoblastoma protein expression in primary non-small cell lung carcinomas. Cancer Res 51: 2735-2739

Xu HJ, Zhou Y, Ji W, Perng GS, Kruzelock R, Kong CT, Bast RC, Mills GB, Li J, Hu SX (1997) Reexpression of the retinoblastoma protein in tumor cells induces senescence and telomerase inhibition. Oncogene 15: 2589-2596

Yakirevich E, Ben Izhak O, Rennert G, Kovacs ZG, Resnick MB (1999) Cytotoxic phenotype of tumor infiltrating lymphocytes in medullary carcinoma of the breast. Mod Pathol 12: 1050-1056

Zhou Y, Li J, Xu K, Hu SX, Benedict WF, Xu HJ (1994) Further characterization of retinoblastoma gene-mediated cell growth and tumor suppression in human cancer cells. Proc Natl Acad Sci USA 91: 4165-4169 